\title{
Educational Innovation in Art Design under the Influence of Design Championship
}

\author{
Yonghua Jing \\ Minsheng College \\ Henan University \\ Kaifeng, China, 475004
}

\begin{abstract}
Under the profound influence of market economy, contemporary art design education has to keep pace with the times, which makes the establishment and perfection of new cultivation mechanism the crucial support for the educational innovation in art design in colleges and universities. The "studio" mode of Bauhaus in pre-war Germany had offered the possibility to establish the objective of practical talents training. While within a new social environment, the coalition of college and enterprise, strengthening of social practice and integration of excellent resources both inside and outside school all have provided new approaches for the development of art design education mode. And there shall be favorable design education and teaching mechanism to guarantee the effective operation of the practice teaching mode in art design major. Only until the school-enterprise operation mechanism has been established on the basis of equality and mutual benefit as well as complementary advantages can both university and enterprise give play to their initiative and achieve a win-win situation.
\end{abstract}

Keywords-design championship; art design; educational innovation

\section{INTRODUCTION}

Under the profound influence of market economy, contemporary art design education has to keep pace with the times, which makes the establishment and perfection of new cultivation mechanism the crucial support for the educational innovation in art design in colleges and universities. The "studio" mode of Bauhaus in pre-war Germany had offered the possibility to establish the objective of practical talents training. While within a new social environment, the coalition of college and enterprise, strengthening of social practice and integration of excellent resources both inside and outside school all have provided new approaches for the development of art design education mode.

\section{ORgAnizATION OF THE TEXT}

\section{A. With renewal of ideas about "studio" mode under the influence of Bauhaus, to carry out studio teaching mode based on the design education and teaching practices}

Driven by the market economy, it has become the art design education running aim to establish the new educational mechanism in art design and to cultivate the outstanding design talents able to be integrated with the world market. In this new context, the art design education shall grasp the characteristics of the era, proceeding from the current educational realities in China and drawing lessons from successful examples at home and abroad, to actively promote the construction of studio cultivating mode in art design major according to local situations.

Formed under the influence of German Bauhaus School of Design, the "studio" teaching mode in art design is currently the main design education mode in art colleges and comprehensive universities of Britain, France, Germany and other European counties, and it also has been on trial for years in some professional art design institutes in China. Generally, the "studio" teaching mode is directed by renowned teachers who have extensive experience in a certain design field. The reason that German Bauhaus University before the Second World War was founded was to adapt to the changes in mass' $\mathrm{s}$ new design demands caused by the changes of social environment, and Bauhaus was just generated in this kind of turning point. The establishment of this new education system in art design is not only a transformation of the European traditional mode of design for art' $\mathrm{s}$ sake insulated from market economic impact but also an experimental attempt based on the aim of serving the society under the current circumstances.

The trial site in China, for instance, "the 7th Design Studio" led by professor Xiao Yong in Design School of China Central Academy of Fine Arts, under the leadership of the mentor, is able to provide advanced design concept for students and maintain close contact with market trend, by using favorable advantages and through participation in social design projects directed by teachers, make students fully play their learning initiative to further understand the production process of design project, help them with the accumulation of design experience, effectively foster their spirit of teamwork, and via design practice ensure them to learn the knowledge and experience which cannot be acquired from the classroom simulation task, so as to lay a solid foundation for independently completing the design project after graduation, which is also a strong point of the "studio" design education mode. 


\section{B. Comprehensive qualities of the navigator in studio teaching mode}

The parallel development of hardware and software is indispensable for the perfection of educational development pattern during the design education and teaching. A critically important step to improve the effectiveness of integrated practice teaching in the whole process is to build the stable practice teaching team with high quality, which is one of the essential conditions for software. Only teachers with certain artistic theoretical accomplishment, unique innovative design capability, rich practical experience in art design and accurate aesthetic judgment can be competent for the practice teaching work and become the navigator in studio teaching mode.

Therefore, the school shall adopt various forms to do a better job in teachers' training and recruiting, and meanwhile strengthen the teachers' business association with other universities and related design industries. To integrate with the society, the teachers not only need to face the school recruiting pressure but also shall improve the adaptability of their own consciousness in academic construction. In that way, the teachers shall strengthen the knowledge update, timely grasp the new design trend in the market and improve the professional accomplishment as well as academic level. The renewal of teachers' new knowledge and new design concept is a most crucial factor in educational and teaching reformation, and moreover is a basic condition for students' integration with the society.

Adhering to the idea of cultivating applied talents, promote the new concept of design education, through scientific approach, mobilize the combinations of production and study, theory and practice, art and technology, thereby forming the new design education mode based on combination between school and enterprise and interaction between classroom teaching and extracurricular teaching.

1) The reconstruction of objective system of talent cultivation in art design major aims to help students with their harmonious development of professional theory knowledge, practical ability and artistic comprehensive quality. In accordance with the "two-strong and one-high" (strong knowledge about basic theories, strong technique applying ability, broad knowledge background and high comprehensive quality) principle, reconstruct the structure of knowledge, ability and quality of the talents majoring in art design with the purpose of cultivating top-class applied talents possessed of " both theoretical knowledge and artistic innovation skills". At the same time, strengthen the cultivation of students' practical and creative abilities and attach great importance to the cultivation of literary accomplishment.

a) There are two indigenous cultivation modes among Chinese traditional education patterns, which respectively are Liberal Education and Technicality-oriented Education. Following the social development, the significance of technique has been accordingly reinforced and the improvement of applying ability even has become the criteria to measure the students' level. b) Even though the cultivation of applied talents has become the main trend of social development, the building of theoretical attainment certainly cannot be ignored. Therefore, the combination of theory and practice is one of the steps of art design education reform, which makes the cultivation of applied talents only be achieved by the construction of certain systems.

2) The reconstruction of process system of talent cultivation in art design major aims to form the "studio" teaching mode with combination involving production, teaching and research. Since the education process determines education results, the construction of education process takes on even more importance for the practice-emphasized art design major. Based on the step-by-step principle, gradually cultivate the art-oriented students into skill-oriented design talents by adding practical courses.

3) Establish the "vertically in-depth" system through the reformation of " studio" teaching mode and reconstruction of curriculum system. Specific to theoretical courses, proceeding from the structure of students ' knowledge, ability and quality, rebuild the curriculum structure and update the teaching content based on the principle of "laying solid foundation, strengthening practice and highlighting innovation". While the practice teaching system in art design major is constructed through three modules including classroom training, task practice and studio practical training. Alternate the theoretical courses teaching with practice teaching in vertical and have them interpenetrated with each other in horizontal, thereby gradually forming the new design teaching system with dynamic integration of knowledge, ability and quality.

4) The effective integration of professional talent resources both inside and outside school aims to build reasonable and creative teaching staff teams. The shortage and unreasonable structure of teacher resources in art design major are currently the most common problems found in colleges and universities. Although external teachers may be able to fill the gaps, it' s quite difficult to manage them as well as to effectively control and guarantee the teaching time and teaching results, thus, external teachers cannot really solve the problems for most colleges and universities. However, the employment of mentors in "studio" mode breaches the limits on the class content and place of external teachers, giving studio teaching the maximum free space, mostly increasing the enthusiasm of teachers and students and allowing students to participate in the practice on the basis of theoretical courses learning.

a) Under the circumstance of external education, teachers with certain practical experience shall be hired as mentors of the studio who will give students proper guidance, help them quickly be in line with the social needs and motivate their passion for learning. As the external teachers can offer more social knowledge which cannot be given by school teachers to enable students to learn the social needs, the 
introduction of such utility personnel is also one of the key factors of educational system reform in art design.

\section{Construction of school-enterprise cooperative design education system guided by market demand}

To survive and develop, enterprises must rely on talents and universities must depend on the cultivation of talents who are competent for the job right after graduation and are highly competitive. Liberal Education aims at the cultivation of students' artistic accomplishment; while skill-oriented education mode is the real trend of cultivation in contemporary society, which breaks with the tradition of preferring doctrines to techniques in traditional education pattern, in other words, it' $\mathrm{s}$ a transformation of the traditional design education concept.

In design education, energetically developing the skilloriented education has become an important policy for the educational reform and development in China. Given this, majors desired by modern production as well as courses equal or similar to occupation post and post cluster shall be offered by the schools, which requires the universities, according to design industry development, corporate strategic adjustment and job changes and requirements, to properly adjust the specialty setting and teaching content based on the universities, nature and orientation and cultivate large numbers of talents with sustainable development capacity. Therefore, the universities shall treat their own teaching work with a developmental view, take the initiative to maintain contact with enterprises and introduce the enterprise into classes during curriculum settings and teaching activities. In addition, dominant platforms shall be built and various practice ways shall be created.

1) New design education and teaching activities include building social practice platforms and creating various practice ways. The particularity of art design education determines its non-uniform patterns and standards around the world. Since China covers a vast geographic area and there have been many differences in regional culture and economic background from place to place as well as evident regional difference in education idea and school-running level, the practice teaching system in art design major shall be appropriately, reasonably and perfectly constructed based on the different provincial conditions and market demands, creating various practice ways, trying to get out of the collegebound practice teaching mode and combining with society and enterprises so as to make the art design practice integrated with market application and effectively enhance the employability of students in art design major.

2) Strengthen the construction of practice base and improve the efficiency of specialty practice teaching. Specialty practice is a practice teaching mode generally used in art design education and an important way to evaluate the teaching quality and improve the students' employability, which, however, due to the differences in regional economy, school-running conditions and practice teaching ideas, cannot be effectively implemented for a long time. In some specialties, because of the lack of practice base, students have to find internship units by their own during specialty practice. While such short-term procedure usually results in the rejection from enterprises for reason of disturbing the corporate internal operation or normal work order. There is another situation: after being accepted by some enterprises, the students are not allowed to participate in substantial design work, which makes them fail to apply what they have learned into the practice. Some internship units that students have found by themselves have nothing to do with their major, which makes the specialty practice the short-term part-time job. This specialty practice course without necessary internship fund and long-term feasible plan performs practically no function and definitely will not achieve the goal of cultivating talents with comprehensive practical ability. Therefore, it' $s$ imperative to combine with the local realities and strengthen the construction of practice base, make necessary capital investment, conduct necessary management and establish long-term cooperative relationship with enterprises, companies and other social units, so as to guarantee the practice teaching results of specialty practice course.

Through mutual communication between schools and internship units, ensure that the students are able to combine the knowledge they have learned with social practice so as to find out their deficiencies and further give school the feedback, thereby promoting the next-step perfection of education and teaching system.

The interactive teaching between professional teachers, corporate designers and students will promote the students' further growth, and meanwhile feedbacks to the design results will be given to check the practicability of the knowledge that students have acquired in the teaching process.

3) The cooperation between school and enterprise broadens the approach of students' comprehensive practice. Through interschool cooperation and mutual assistance, carry out the reformation and innovation of practice teaching contents and methods, give full play to respective discipline advantages and widen the field of design practice. At the same time, expand the scope of school-enterprise cooperation, combine the professional design curriculum with corporate design task project and try to appoint professional teachers and corporate designers as the project instructors, so as to offer students more opportunities to connect with the society and participate in the practice and further make students' design practice more operational and targeted.

4) Conduct social practice communication activities to effectively enhance students' comprehensive practical ability. By making full use of social resources, organizing the participation in competitions, exhibitions and holiday social practices as well as the collective participation in social design projects, create more practice opportunities for students, cultivate their comprehensive specialty literacy and artistic accomplishment and improve their abilities of design practicing, communication and team collaboration. In good 
time, introduce students design works especially the excellent graduate design works to the market. For the design works with outstanding performance in artistry, designability and practicability, we will break the school-collecting habit and seek for suitable market and timing, which can not only improve the degree of social recognition for students' design works, realize the works market achievement transformation but also effectively mobilize the students' enthusiasm for design practice.

a) The transformation and trail from traditional artoriented design task to applied or market-oriented design task is not only very helpful for the art design education and teaching but also is able to arouse students' enthusiasm.

b) All pamper imaginations with the purpose of cultivating skilled talents are the practice-based reformation, a new mode which is designed to promote the theory teaching depending on practical skill operation through the combination of classroom and site. The "zero-distance" contact between students and enterprises allows students to participate in the corporate production and management while learning, and moreover makes students more social in nature and more aligned with the direction of social development, enabling students to meet demands of corporate development and shaping them into real high-skilled talents who are down-toearth, reliable and helpful.

\section{CONCLUSION}

Anyway, the effective operation of practice teaching mode in art design major shall be guaranteed by favorable design education and teaching mechanism. Only until the schoolenterprise operation mechanism has been established on the basis of equality and mutual benefit as well as complementary advantages can both university and enterprise give play to their initiative and achieve a win-win situation. The successful implementation of the new teaching mode has a bearing on the major trend of art design specialty development, and also has broader relevance for the career prospects of students in this major, which remains to be explored later on.

\section{REFERENCES}

[1] Lu Ying, History and Aesthetics of Visual Communication Design [M], Beijing: China Renmin University Press, 2000.

[2] Zhang Liguo, Design Art Aesthetics [M], Jinan: Shandong Education Press, 2002.

[3] Zhu Di, Contemporary Western Aesthetics [M], Beijing: People' s Publishing House, 1984

[4] Herbert Read, Education Through Art [J], Hunan Fine Arts Publishing House.

[5] Viktor Lowenfeld, Creative and Mental Growth [J], Hunan Fine Arts Publishing House. 